\title{
Causing Factors of Urban Sprawl Symptoms in Peri-Urban Areas of Singaraja City, Bali Province
}

\author{
I Gede Wyana Lokantara ${ }^{*}$ \& Farisa Maulinam Amo ${ }^{1}$ \\ ${ }^{1}$ Urban and Regional Planning, Universitas Terbuka, Jalan Cabe Raya Pondok Cabe, Pamulang \\ Tangerang Selatan 15347, Indonesia; *Corresponding author. e-mail:igede-wyana@ecampus.ut.ac.id \\ (Received: May 21st, 2021; Accepted: August 6th, 2021)
}

\begin{abstract}
The development of a city is marked by an increase in population and an increase in the need for space, which causes the city to be unable to accommodate its activities. Hence, physical development of the city to the peri-urban area and urban sprawl occurs. This also happened in Singaraja City, Bali province as proved by the increasing development of settlements in the area. The purpose of this research is to identify the development of Singaraja City spatially by looking at the pattern of city development due to the influence of the urban sprawl and to identify the factors that influence its development. This study used qualitative methods to analyze the spatial transformation through mapping techniques using time series data developed regions and non-woke Singaraja City, so discovered patterns development impact suburban of Singaraja City. It further analyzed the determinant factors causing urban sprawl in suburban Singaraja. The research shows that Singaraja City has experienced urban development towards the suburban of the city by forming a leap-frog development pattern. The suburban of Singaraja City that are most dominantly affected are the western and eastern regions, namely Baktiseraga Village and Banyuning district. The dominant factor that causes urban sprawl in suburban Singaraja City is people's desire to conduct commercial activities amounting to $94.67 \%$ with the opening of shops and services to facilitate the needs of students or migrant workers. The emergence of new economic activities initiated by the surrounding population, causing the orientation of economic transformation in the suburbs of Singaraja city to switch to the non-agricultural sector.
\end{abstract}

Keywords: leap-frog development, peri-urban, urban sprawl

\section{INTRODUCTION}

The increasing development activities in various cities in Indonesia also increase economic growth. The activities of the urban population that are increasingly varied in the economic, social and cultural sectors have the potential to increases land demand, as a result the availability of land also increases (Desiyana, 2017). Land settlement to be very limited in the city centre due to land prices are relatively expensive and limited. This condition causes the space in the city to be unable to accommodate the activities and the existence of its inhabitants, on the other hand, the limited administrative boundaries have resulted in the development of urban activities towards the suburban areas (Pratama \& Ariastita, 2016).

While the growth of the population in all aspects of life, which lasts continuously will result in the flow of population mobility is increasing and it will affect the quality of the environment, both air and water quality (Hidayat et al., 2017). The transformation of urban areas causes what happens in urban areas to peri-urban areas causing a process of spatial transformation 
in the form of a settlement densification process and socio-economic transformation as a followup impact of the spatial transformation process (Nelson, 1995). The condition of settlement densification in suburban areas is a form of representation of the increasing need for space in urban areas (Khasanah \& Astuti, 2020).

The increasing need for space in urban areas has also occurred in the Singaraja City area, Buleleng Regency, which is marked by a very significant population development and the development of residential areas in the suburbs of Singaraja City. However, an interesting condition is that the Buleleng Regency area is neither a special economic zone nor an industrial area, so it is very important to identify the causes for the development of urban activities in suburban areas (Setyono et al., 2016).

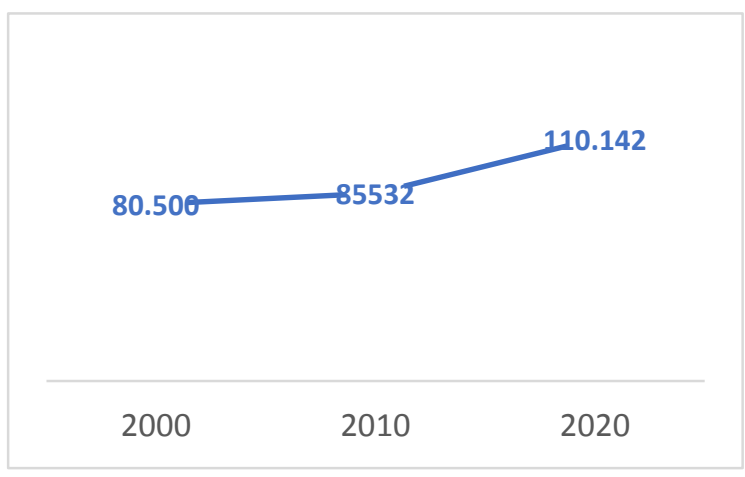

Figure 1. Population Development of Singaraja City in 2000, 2010 and 2020

Source: Kabupaten Buleleng dalam Angka, 2020

Based on analysis of population data Singaraja City in 2000, 2010 and 2020 an increasing number of high populations. The increasing number of residents has consequences for population growth and population density as well as the use of space for both private and public purposes as well as agricultural and non-agricultural activities. If this condition can't be controlled, the use of built land, especially the provision of residential land, commercialization and even affects the quality of the environment (Giyasih, 2017).

The use of secondary data results that include an analysis of population mobility land use activities, and economic activities are expected to provide an overview of the factors that drive the transformation of the peri urban area, Singaraja City. The purpose of this research was to identify the factors that influence the development of urban sprawl that occurred in the suburbs of Singaraja City which were analyzed through the transformation of social and economic activities of the residents of Singaraja City. Urban sprawl phenomenon as a process that is happening in the development of a city and in this case is Singaraja City, and it is impossible to stop its spread to the peri-urban area of Singaraja City, so it is considered important to control, on the one hand in order to reduce vulnerability to urban sprawl threats, and on the other hand can reap positive opportunities from urban sprawl, both in terms of physical, socio-cultural and economic (Christiawan, 2018).

\section{METHODOLOGY}

\section{Research Approach}

This study uses a qualitative approach to identify the factors that causing urban sprawl to transform the Singaraja urban area. As an effort to strengthen these findings, it will first be studied about the development of urban sprawl in the suburbs of Singaraja City by using an indicator of the amount of green land used for settlement, trade, and service activities. It's just that the indicator used is the occurrence of land conversion in Singaraja City. The factors that causing urban sprawl on the outskirts of Singaraja City will be studied based on economic activities, social activities and environmental conditions.

\section{Data Collection Technique}

Data collection techniques are carried out through primary data collection such as conducting structured interviews aimed at selected informants who live in the suburbs of Singaraja City. They were selected using purposive sampling. Regarding the observation activities in the existing area, it is adjusted to a survey instrument that focuses on the situation of growth in the suburbs of Singaraja City. Primary data collection was carried out through identification of urban sprawl conditions 
obtained from Landsat 8 imagery, and Google Earth imagery for 2000 to 2020 (Hardari, 2011).

\section{Data Analysis}

Spatial data in this study describes the development of the area seen from land use change activities such as for settlements, economic activities and road networks in the peri-urban area of Singaraja City (Muta'ali, 2011). The results of the spatial analysis of the peri-urban area of Singaraja City due to the urban sprawl phenomenon, describe the spatial development pattern of various phenomena that occur. The following are some criteria for analyzing aspects of physical development due to urban sprawl in the peri-urban area of Singaraja City:

Table 1. Criteria for the Development of Urban Sprawl From a Physical Aspect

\begin{tabular}{lllc}
\hline \multicolumn{1}{c}{ Variable } & \multicolumn{1}{c}{ Criteria } & \multicolumn{1}{c}{ Grade } & Score \\
\hline Building & $\begin{array}{l}\text { Land built } \\
\text { Density }\end{array}$ & Low & 1 \\
& $\begin{array}{l}\text { Land built } \\
\text { 50.000 ha }\end{array}$ & Medium & 2 \\
& $\begin{array}{l}85.000 \text { ha } \\
\end{array}$ & & \\
\cline { 2 - 4 } & $\begin{array}{l}\text { Land built }> \\
\text { 85.000 ha }\end{array}$ & High & 3 \\
\hline Accessibility & Not yet & Zero & 0 \\
\cline { 2 - 4 } Level & $<1500$ meter & Low & 1 \\
\cline { 2 - 4 } & $\begin{array}{l}1500- \\
\text { meter }\end{array}$ & Medium & 2 \\
\cline { 2 - 4 } & $>3000$ meter & High & 3 \\
\hline Land Use & Agriculture & & 1 \\
\cline { 2 - 4 } & $\begin{array}{l}\text { Street, } \\
\text { public } \\
\text { facility }\end{array}$ & Built & 2 \\
\cline { 2 - 4 } & $\begin{array}{l}\text { Cities } \\
\text { activities }\end{array}$ & Built & 3 \\
& & & \\
\hline
\end{tabular}

Furthermore, an analysis of the factors that influence the occurrence of urban sprawl based on social and economic activities in the peri-urban area of Singaraja City is carried out. This analysis uses 100 respondents who were randomly selected using the main indicator in the form of changes in economic activity from agriculture to non-agricultural activities. In more detail, the following are the criteria (Dahroni, 2018).
Table 2. Criteria for Urban Sprawl Development in terms of Social and Economic Aspects

\begin{tabular}{llll}
\hline \multicolumn{1}{c}{ Variable } & \multicolumn{1}{c}{ Criteria } & \multicolumn{1}{c}{ Grade } & Score \\
\hline Economic & Agriculture & Low & 1 \\
\cline { 2 - 4 } activity & $\begin{array}{l}\text { Mix, } \\
\text { agrarian } \\
\text { dominant }\end{array}$ & Medium & 2 \\
\cline { 2 - 4 } & $\begin{array}{l}\text { Non- } \\
\text { agrarian }\end{array}$ & High & 3 \\
\hline Land & $\begin{array}{l}\text { Agrarian } \\
\text { Ownership }\end{array}$ & Low & 1 \\
& Dominant & & \\
\cline { 2 - 4 } & Sell land & Medium & 2 \\
\cline { 2 - 4 } & $\begin{array}{l}\text { Commercial } \\
\text { dominant }\end{array}$ & High & 3 \\
\hline Public & Not yet & Low & 1 \\
\cline { 2 - 4 } Service & Basic & Sedang & 2 \\
\cline { 2 - 4 } & High Service & Tinggi & 3 \\
\hline
\end{tabular}

\section{RESULTS AND DISCUSSION}

\section{Singaraja City Development Spread into the Peri Urban Area}

Identification of urban sprawl conditions in urban development that occurred in Singaraja City underwent a process of change in different periods of time. This can predominantly occur in certain parts of the region, especially in suburban areas. Changes in spatial development in Singaraja City consist of the use of built-in land as seen in changes in land use to build residential areas. The increasing population in Singaraja City has also affected land use conditions.

This increase in population is directly proportional to the resulting activities so that it requires land to accommodate the activities that occur. Land that was originally non-built has turned into built, such as residential and commercial areas dominating the Singaraja City area. The results of the analysis show that there is a built-in land use in Singaraja City. Development of commercial areas such as shopping complexes, malls and social facilities/ public services as well as rows of shophouses in residential areas. Based on the analysis of ALOS AVNIR-2 image data from 2010, 2015 and 2020 , there are changes in land use in several locations on the Peri Urban of Singaraja City.

Changes in land use are used for residential areas. Significant land conversion 
occurred in Baktiseraga Village which experienced an increase of 234 ha in 2020 and Banyuasri Village increased by 286 ha in 2020. This change occurred due to housing development by developers in providing shelter for the community, thus makes agricultural land converted into built-up land. Changes in the function of open land, such as paddy fields and moor, don't directly change the function of becoming developed and developing land as well as land for commercial economic activities. In general, rice fields and moor are opened and temporarily turned into empty land that is ready to build or make plots of land. While the area of Banyuning Village experienced the most complex spatial changes compared to other areas, this can be seen from the widening variety of population activities in this village area which almost resembles central urban activities. More details can be seen in Figure 2 below.

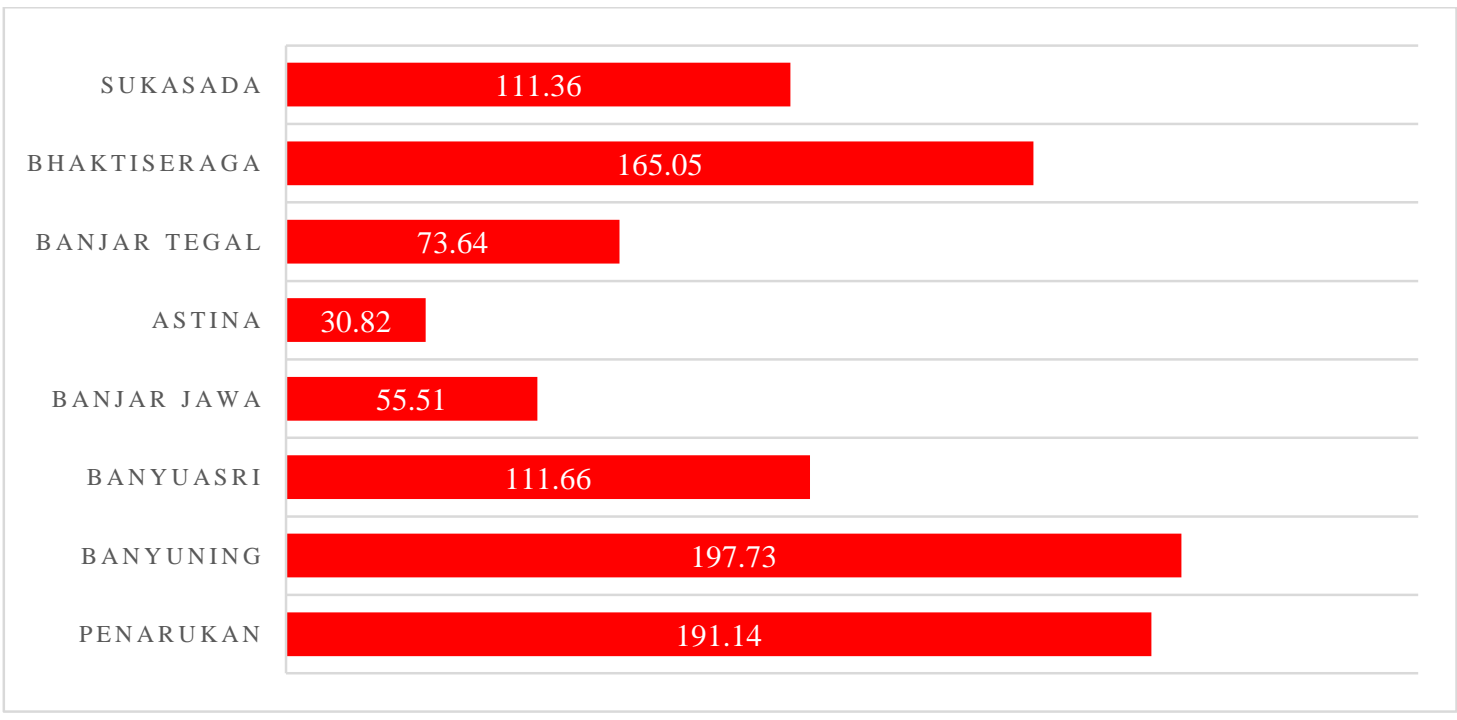

Figure 2. Land density area in Peri-Urban Singaraja

The results of the spatial analysis of urban areas and their suburbs show quite rapid differences over a period of 20 years. The total of urban land cover in ten years has experienced an increasing growth, causing the expansion of the built-up area to various points in the suburbs of Singaraja City. This shows that urban activity in the Singaraja City area is an area that grows rapidly and spreads to the Peri Urban of Singaraja City which is influenced by a high number of settlements due to the increasing pressure for housing needs for the community and land use for commercial or economic activities. Based on the results of the spatial mapping analysis of the development of Singaraja City, there has been a significant change that has spread to the areas of

Banyuning Village, Bakti Seraga Village and Banyuasri Village. The three village areas are located very close to the center of Singaraja City. The sprawl characteristics that have been calculated based on the number of built-up areas and commercial land use, it is identified that the highest sprawl development direction gets the total score of the urban sprawl level.

After obtaining the total score for each sprawl identified sub-district, the typology of development of the suburbs that has approached a symptom resembling the center of Singaraja City is classified as the eastern part of the area which is included in the main affected area consisting of Banyuning Village and Kampung Baru Village. This is evidenced by the development of urban activities such as residential areas such as housing, the growth of commercial areas, public facilities, and road networks.

Based on the analysis above, the type of urban sprawl that occurs in the Peri Urban area of Singaraja City is included in the type of leaf frog development, its characteristics can be seen from several patterns of urban development that 
occur sporadically outside the main built area and the new development area formed is in the middle of an area that is undeveloped, the emergence of new built-up areas that are not integrated with the main built-up area and are mediated by undeveloped land which is usually productive agricultural land.

The urban sprawl type of Singaraja City which moves to the East and West is triggered by the development of urban infrastructure such as commercial areas, education services, housing and health services, as happened to the Banyuning Village and Baktiseraga Village. This can be done because of the support of the road network that reaches the peri-urban area of Singaraja City. The ability of the city center to provide services is able to encourage the pace of development in peri-urban areas

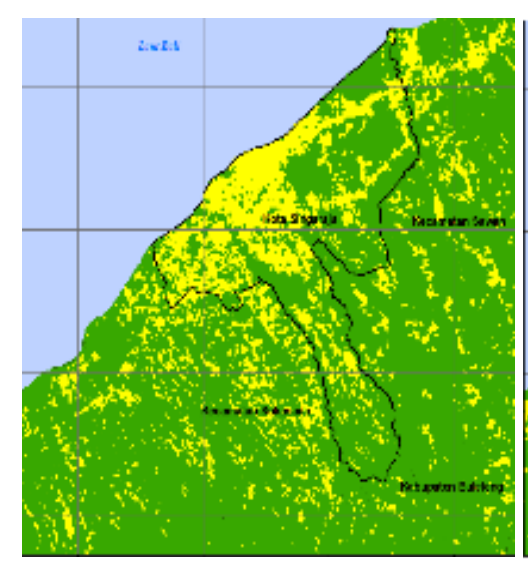

Year 2000



Years 2010

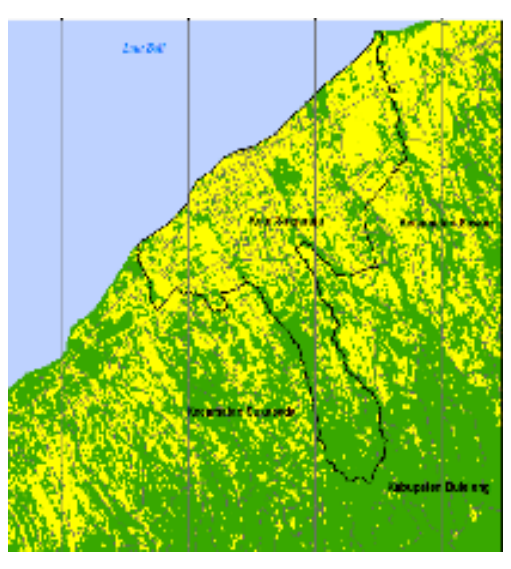

Years 2020

Figure 3. Built-in Land Use Map (2000, 2010, 2020) in the Singaraja Peri Urban Source: Landsat Image Analysis 8, 2020

However, there are development obstacles such as urban sprawl that occurs in the eastern and western areas which gradually trigger traffic density and built-up land, so anticipatory steps are needed to overcome these problems.

\section{Determinant Factors Causing of Urban Sprawl in the Peri Urban of Singaraja City}

Giyarsih (2017) has conducted an analysis of the urban sprawl phenomenon in the city of Yogyakarta. His research has concluded that the phenomenon of urban sprawl is in the suburban area (urban fringe) and results in the conversion of agricultural land to nonagricultural land. Henceforth, the conversion process of agricultural land to non-agricultural resulted in the densification process (compaction) of settlements in suburban areas.
The resulting impacts include socioeconomic, cultural and physical environments. In the previous analysis, it is known that Singaraja City is experiencing urban development towards the suburbs of the city, which moves east and west by forming a leapfrog development pattern. This is indicated by the emergence of a very significant land use change towards the Peri Urban of Singaraja City, which has become a new residential area (Budihardjo, 2009).

In this case, Bhaktiseraga and Banyuning District still provide open land such as rice fields and moor which can be developed at any time into built-up land. Based on the analysis of the development of housing areas, it shows that the development of housing units is dominated by residential or subsidized housing development and rental housing. 


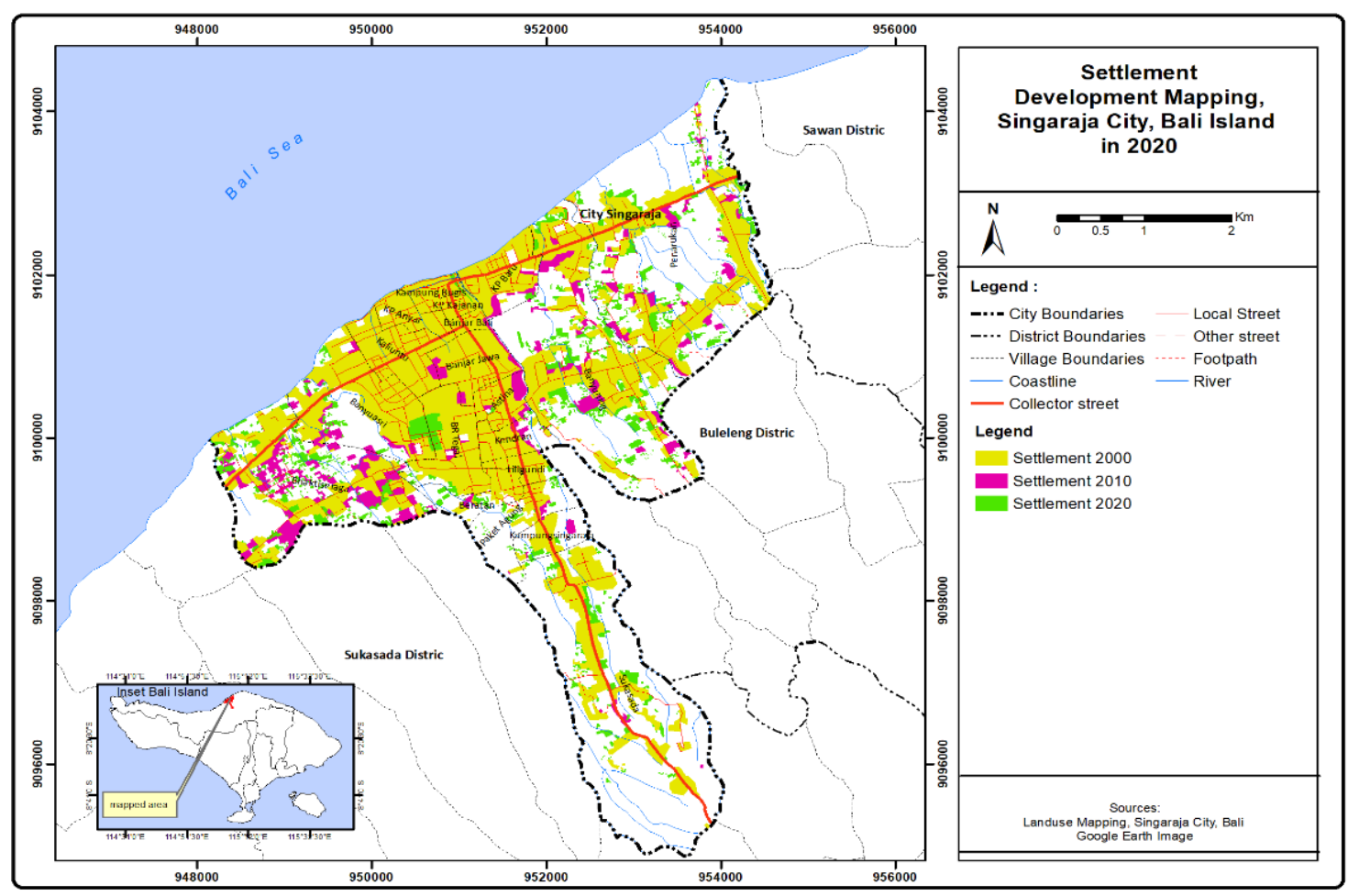

Figure 4. Settlement Development Mapping in Peri Urban of Singaraja City Source: Google Earth Image, 2020

This rental housing is provided for students or migrant workers who wish to continue their education in Singaraja City, considering that there are many universities in this city, one of which is the Ganesha Education University. The need for housing originating from the immigrant population causes open land to be used to build housing, both private houses and for rent. The increase in building density from 2010 to 2020 is shown in the built housing areas and along road corridors that functions have dominated. Commercial or trade facilitate buying and selling transactions and service activities. Trade and services in Singaraja City and its suburbs contribute to or influence the economy in the surrounding area. This is indicated by the existence of commercial buildings with a scale of city services and shophouses.

Based on the survey results, the factors that most influence the occurrence of urban sprawl in the Peri Urban area of Singaraja City are residents tend to carry out economic activities. The main activity carried out is using the land to open a business such as shops, stalls and other services, which reached $94.67 \%$. They opened the business, to provide to meet the needs of students and other immigrant residents. This finding is in accordance with Baiquni and Muta'ali (1998) opinion, which states that the factor driving the transformation of regions and cities is economic growth, which encourages spatial development in the city center and crosses urban administrative boundaries to the suburban areas. Therefore, there will be expansion of settlements on the Peri-Urban of the city and even population growth and the activities of small towns (sub-districts and villages) that are close together, causing the development of integrated corridors. In addition, another factor that causes urban sprawl in the peri-urban area of Singaraja City is the desire of immigrants to fulfill their housing needs with a score of $86.67 \%$. They prefer to buy houses in suburban areas because the prices are relatively cheaper. 


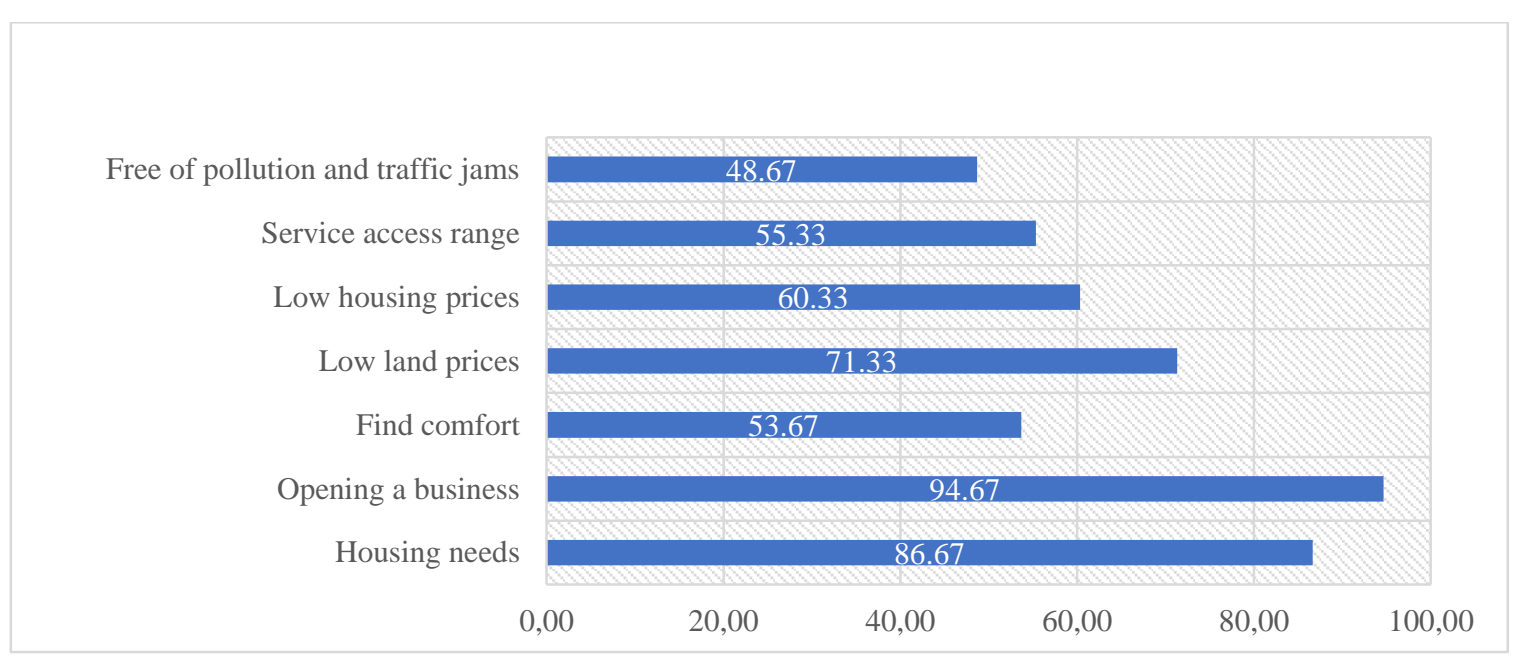

Figure 5. Factors that affect the symptoms of urban sprawl in the peri-urban area of Singaraja City Source: Secondary Data Analysis, 2021

The factors that determine the change in the Peri Urban of Singaraja City are changes in land use into built-up areas such as housing and commercial activities including trade, services that can serve the needs of local migrants such as students and workers. Migrant residents who live in the suburbs of Singaraja City display urban life activities. This immigrant lifestyle indirectly becomes a reference for local residents who gradually follow the pattern of life activities of the immigrant population. Local residents also become a consumptive society, and prioritize materialistic considerations in various decision-making.

The life of the immigrant population to carry out commercial activities such as establishing boarding houses or renting houses, opening shops and other services to serve the needs of the immigrant population, especially students, and these activities try to be followed by local residents who actually make up the majority of work as farmers. Selling agricultural land is a shortcut for farming families to follow an urban lifestyle, or simply to fulfill the wishes of children and families, which are often not even needed by them. The secondary negative impact of this economic issue is the loss of jobs as farmers and land productivity.

The existence of villages located in periurban areas in terms of the physical influence of the existence of Singaraja City, encourages faster changes in community economic activities in peri-urban areas (Soetomo et al., n.d.). This causes the existence of the peri-urban area to be inseparable from the social, cultural, and economic center of the nearest urban area, which causes changes in the structure of population activities in the city. These factors drive the transformation stage of the Singaraja City area due to economic growth that encourages spatial development from the city center to the peri urban area.

This condition has led to the development of new corridors in the form of infrastructure development and road network towards the city's outskirts, which encourages new growth along the access so that it becomes a city expansion area. The impact of urban sprawl in the peri-urban area of Singaraja City causes many roads and roads to become longer because the composition of land functions is far from each other to be accessed by foot. More roads means more vehicles. The city provides roads for vehicles and provides options for public transportation, but the quality of public transportation is less plentiful and comfortable so that more people use private vehicles.

Side effects of urban sprawl caused by poor environmental quality, both air and water quality. However, urban sprawl is not always bad if it is handled with an efficient and correct strategy. The application of smart growth is one option to reduce environmental damage caused by urban sprawl. The Singaraja City 
Government as the holder of power must plan and control the development of the city so that the city environment becomes more livable.

\section{CONCLUSIONS AND RECOMMENDATION}

Singaraja City is experiencing urban development towards the outskirt of the city, which moves east and west by forming a leapfrog development pattern. This is indicated by the emergence of a very significant land use change towards the Peri Urban of Singaraja City, which has become a new residential area. In this case, Baktiseraga and Banyuning District still provide open land such as rice fields and moor which at any time can be developed into built-up land. The dominant factor that causes urban sprawl in the Peri Urban of Singaraja City is the effect of carrying out economic activities of $96.67 \%$ by choosing to open shops and services to facilitate the needs of students or migrant workers called migrants.

This economic growth factor drives spatial development in the city centre and crosses the city administrative boundaries to the Peri Urban of Singaraja City. Based on this, it is necessary to have regulations that can control the development activities of residential areas by developers including illegal settlements without ignoring the needs of settlements in line with population growth. In addition, it is also necessary to arrange an area for economic activities such as shops, markets, shop houses which causing crowded and slum areas (Rohmadiani, 2020).

\section{ACKNOWLEDGMENT}

Thank you to those who have helped in the implementation of this research, especially the head of the regional and urban planning study program at the Open University, Bappeda Buleleng Regency, and BPS Buleleng Regency so that the research can be completed properly.

\section{REFERENCES}

Badan Pusat Statistik (BPS) Kabupaten Buleleng. 2020. Kecamatan Buleleng dalam Angka 2020. Kabupaten Buleleng.

Baiquni \& Muta'ali. (1998). Depopulasi Perdesaan di Daerah Istimewa Yogyakarta. Yogyakarta: UGM Press.

Budihardjo, E. \& Sujarto, D. (2009). Kota Berkelanjutan (Sustainable City). Bandung: P.T. Alumni.

Christiawan, P. I. (2018). Antisipasi Dampak Negatif Urban Sprawl pada Wilayah Pinggiran Kota Denpasar. Seminar Nasional Hukum Dan Ilmu Sosial Ke - 2, 2(Merekonstruksi Ilmu Hukum dan Ilmu Sosial dalam Membangun Karakter Bangsa), 1-5.

Dahroni, Setiyadi, N. A., \& Arozaq, M. (2018). Perkembangan Dan Karakteristik Permukiman Urban Sprawl Kecamatan Kartasura, Sukoharjo Terhadap Kerentanan Banjir Sungai. Prosiding Seminar Nasional Geografi UMS IX 2018 ISBN: 978-602-361-137-9.

Desiyana, I. (2017). Urban Sprawl Dan Dampaknya Pada Kualitas Lingkungan: Studi Kasus Di Dki Jakarta dan Depok, Jawa Barat. Jurnal Komunikasi Visual, X(2), 16-24.

Giyasih, S. R. (2017). Regional management of areas with indications of urban sprawl in the surrounding areas of universitas muhammadiyah, Yogyakarta, Indonesia. Indonesian Journal of Geography, 49(1), 3541. https://doi.org/10.22146/ijg.2323

Hardari, P. (2011). Transformasi wilayah peri urban. kasus di Kabupaten Semarang. Jurnal Geografi, $\quad 8(2), \quad$ 108-117. https://doi.org/10.15294/jg.v8i2.1661

Hidayat, O., Pontoh, N. K., \& Prasetya, D. B. (2017). Perkembangan Urban Sprawl ditinjau dari Aspek Fisik Pada Wilayah Peri Urban Kota Bandar Lampung ( Studi Kasus : Kecamatan Tanjung Senang, Kota Bandar Lampung dan Kecamatan Jati Agung , Kabupaten Lampung Selatan ). 1-9. http://repo.itera.ac.id/depan/submission/SB18 $11140030 \% 0 \mathrm{~A}$

Khasanah, M. \& Astuti, D. W. (2020). Memahami Urban Sprawl: Analisa Perkembangan Permukiman Kota Salatiga Dengan Digitasi Arcgis. Langkau Betang: Jurnal Arsitektur, $7(2)$, 151. https://doi.org/10.26418/lantang.v7i2.41869 
Muta'ali, L. (2011). Kapita Selekta Pengembangan Wilayah. Yogyakarta: Badan Penerbit Fakultas Geografi (BPFG) Universitas Gadjah Mada

Nelson, A. C. \& Duncan, J. B. (1995). Growth Management Principles and Practices. Chicago: Planners Press.

Pratama, I. P. P. A., \& Ariastita, P. G. (2016). Faktor - Faktor Pengaruh Ukuran. Jurnal Teknik Its, $5(1), 1-6$.

Pontoh, Nia, K. \& Kustiawan, I. (2008). Pengantar Perencanaan Perkotaan. Bandung: Penerbit ITB.

Rohmadiani, L. D. (2020). Kerentanan Banjir Berdasarkan Tingkat Urban Sprawl. Jurnal Planoearth, $\quad 5(1)$, 52. https://doi.org/10.31764/jpe.v5i1.1267

Setyono, J. S., Yunus, H. S., \& Giyarsih, S. R. (2016). the Spatial Pattern of Urbanization and Small Cities Development in Central Java: a Case Study of Semarang-Yogyakarta-Surakarta Region. Geoplanning: Journal of Geomatics and Planning, 3(1), 53-66. https://doi.org/10.14710/geoplanning.3.1.5366

Soetomo, S., Sipil, J. T., Teknik, F., \& Diponegoro, U. (n.d.). Metropolitan Terhadap Pemilihan Moda Transportasi ( Studi Kasus : Semarang Metropolitan ) Urban Sprawl Impact To the Cities Toward Metropolitan in Choosing the Transportation ( Case Study: Semarang ).

Sutanto. (1986). Penginderaan Jauh Jilid 1 . Yogyakarta: UGM Press

Yunus, H.S. (1978). Konsep Perkembangan Daerah dan Pengembangan Daerah Perkotaan. Yogyakarta: Fakultas Geografi UGM.

Yunus, H. S. (2006). Megapolitan: Konsep, Problematika dan Prospek. Yogyakarta: Pustaka Pelajar.

Yunus, H. S. (2008). Dinamika Wilayah Peri Urban: Determinan Masa Depan Kota. Yogyakarta: Pustaka Pelajar 